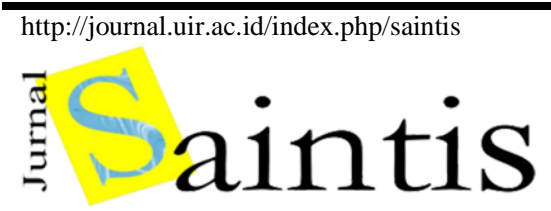

Volume 21 Nomor 01, April 2021 : 31-44

\title{
Studi Optimasi Operasional Waduk Koto Panjang Untuk Pembangkit Listrik Tenaga Air
}

\author{
Study of Koto Panjang Reservoir Operasional Optimization for Hydroelectric Power Plant
}

\author{
Diana Hanafi ${ }^{1, *}$, Harmiyati $^{1}$ \\ ${ }^{1}$ Teknik Sipil, Universitas Islam Riau, Jl.Kaharuddin Nasution 113, Pekanbaru, Indonesia
}

* Penulis korespondensi : dianahanafi@student.uir.ac.id

Tel.: +62-852-6536-8266; fax.:-

Diterima: 21 Januari 2021; Direvisi: 29 April 2021; Disetujui: 29 April 2021.

DOI: 10.25299/saintis.2021.vol21(01).6249

\section{Abstrak}

Pada musim kemarau PLTA Koto Panjang pernah mengoperasikan satu unit turbin dan generator sehingga daya yang dihasilkan tidak maksimal. Pada musim yang sama PLTA ini juga pernah mengoperasikan tiga unit turbin dan generator namun hanya menghasilkan daya listrik $\leq 35 \mathrm{MW}$ dengan prosentase $<50 \%$ yaitu $\leq 30,702 \%$ dari daya maksimal pengoperasian tiga unit turbin dan generator. Tujuan dari penelitian ini adalah untuk mengetahui debit andalan PLTA Koto Panjang, optimalisasi yang dilakukan dalam mengoptimasi PLTA Koto Panjang, daya listrik yang dihasilkan dari hasil optimalisasi tersebut dan perbandingannya. Metode yang digunakan adalah metode empiris Penman untuk menghitung nilai evaporasi. Debit andalan untuk debit outflow PLTA saat ini dan setelah dioptimalisasi dihitung menggunakan rumus daya listrik dan metode mass curve. Selanjutnya debit outflow PLTA yang telah didapatkan dianalisis di dalam tabel water balance menggunakan metode sequent peak analysis. Hasil yang didapatkan adalah debit andalan PLTA saat ini dan setelah dioptimalisasi yaitu 305,319 m³/det dan 384,465 m³/det dengan prosentase 51,995 \% dan $39,235 \%$. Optimalisasi dilakukan dengan menyesuaikan debit outflow dengan volume air yang ada pada storage saat itu. Daya listrik setelah dioptimalisasi adalah sebesar 13.302,315 kWatt pada musim kering dan 143.551,645 kWatt pada musim hujan. Daya listrik yang dihasilkan PLTA saat ini adalah sebesar 13.302,315 kWatt pada musim kering dan $114.000 \mathrm{kWatt}$ pada musim hujan. Sehingga daya listrik yang dihasilkan PLTA setelah dioptimalisasi mengalami kenaikan dari daya listrik sebelum dioptimalisasi sebesar 29.551,645 kWatt. Karena kenaikan daya melebihi kapasitas generator PLTA saat ini, maka terjadi penambahan 1 generator $30.000 \mathrm{kWatt}$ atau 30 MW.

Kata Kunci: Daya Listrik, Debit Andalan, Optimasi, PLTA, Waduk

\begin{abstract}
In the dry season, Koto Panjang Hydroelectric Power Plant has operated one turbine and generator unit so the power produced is not optimal. In the same season, this hydropower plant has also operated three turbines and generators but only produces $\leq 35$ MW of electricity by percentage $<50 \%$ which is $\leq 30,702 \%$ of the maximum power from operating three turbine and generator units. The purpose of this research is to determine the mainstay discharge of Koto Panjang Hydroelectric Power Plant, optimization will be used for Koto Panjang hydroelectric power plant, power can produce from its optimization and its comparison. The method used in this research is the Penman empirical method to calculate the evaporation value. The mainstay discharge for hydropower plant outflow discharge at this time and after being optimized is calculated using the electrical power formula and the mass curve method. Furthermore, the hydroelectric power plant outflow discharge has obtained is analyzed in the water balance table using the sequent peak analysis method. The results obtained are the current mainstay discharge of hydroelectric power plant and after optimization, which are $305,319 \mathrm{~m}^{3} / \mathrm{s}$ and $384,465 \mathrm{~m}^{3} / \mathrm{s}$ with a percentage of 51,995\% and 39,235\%. Optimization is done by adjusting the outflow discharge to the volume of water in the storage at that time. The electric power after optimization is 13.302,315 kWatt in the dry season and 143.551,645 kWatt in the rainy season. The current electricity generated by hydroelectric power plant is 13.302,315 kWatt in the dry season and 114.000 kWatt in the rainy season. Therefore the electric power generated by hydroelectric power plant after optimization has increased from the electric power before it is optimized which is 29.551,645 kWatt. Because the increasing of the electric power exceeds the capacity of the current hydroelectric power plant generator, there is an addition 1 generator which is $30.000 \mathrm{kWatt}$ or $30 \mathrm{MW}$.
\end{abstract}

Keywords: Electrical Power, Hydroelectric Power Plant, Mainstay Discharge, Optimization, Reservoir

\section{PENDAHULUAN}

Waduk adalah wadah buatan yang terbentuk sebagai akibat dibangunnya bendungan. Bendungan adalah bangunan yang berupa urukan tanah, urukan batu, dan beton, yang dibangun selain untuk menahan dan menampung air, dapat pula dibangun untuk menahan dan menampung limbah tambang, atau menampung lumpur sehingga terbentuk waduk [1].
Waduk Koto Panjang merupakan salah satu waduk di Riau yang berlokasi di Desa Rantau Berangin (Merangin), Kecamatan Bangkinang Barat, Kabupaten Kampar, Provinsi Riau. Waduk ini merupakan waduk serbaguna (multipurpose reservoir) yang memiliki fungsi sebagai pembangkit listrik (PLTA), pengendali banjir, perikanan dan tempat rekreasi. Bendungan Koto Panjang yang berlokasi $\pm 20 \mathrm{~km}$ dari Bangkinang atau $87 \mathrm{~km}$ dari 
Pekanbaru ini merupakan bendungan tipe concrete gravity atau bendungan gravitas.

PLTA Koto Panjang mengoperasikan tiga unit turbin dan generator. Namun berdasarkan hasil wawancara dengan Supervisor II Shift C PLTA Koto Panjang menyatakan pada musim kemarau PLTA ini pernah mengoperasikan satu unit turbin dan generator sehingga daya yang dihasilkan tidak maksimal. Pada musim yang sama PLTA Koto Panjang juga pernah mengoperasikan tiga unit turbin dan generator namun hanya menghasilkan daya listrik $\leq 35 \mathrm{MW}$ dengan prosentase $<50 \%$ yaitu $\leq 30,702 \%$ dari daya maksimal pengoperasian tiga unit turbin dan generator.

Berdasarkan permasalahan tersebut, perlu dilakukan penelitian agar operasional waduk terpenuhi untuk PLTA. Penelitian dapat dilakukan dengan mengoptimalkan volume air yang masuk ke dalam waduk Koto Panjang dan pelepasan dari pada air yang telah ditampung tersebut untuk membangkitkan energi listrik. Penelitian ini menggunakan metode mass curve dan metode sequent peak analysis pada tabel water balance (neraca air) dengan debit andalan sebagai debit outflow untuk membangkitkan energi listrik. Oleh karena itu perlu dilakukan suatu studi mengenai optimasi operasional Waduk Koto Panjang untuk pembangkit listrik tenaga air.

Adapun tujuan dari peneilitian ini adalah menentukan debit andalan yang digunakan untuk keperluan PLTA Koto Panjang, menentukan optimalisasi yang akan dilakukan dalam mengoptimasi PLTA Koto Panjang, menentukan besar daya listrik yang dihasilkan PLTA Koto Panjang setelah dioptimasi, menentukan perbandingan besar daya listrik yang dihasilkan PLTA Koto Panjang saat sebelum dan sesudah dioptimalisasi.

Dalam hal ini, untuk memperjelas suatu penelitian agar dapat dibahas dengan baik dan tidak meluas, maka perlu direncanakan batasan masalah yaitu studi ini hanya mencakup fungsi Bendungan Koto panjang sebagai PLTA, tidak memperhitungkan keuntungan secara ekonomi (rupiah) yang didapat PLTA Koto Panjang, tidak memperhitungkan resapan air waduk yang meresap ke dalam tanah, tanah pada dasar waduk diasumsikan jenuh akan air, tidak memperhitungkan desain sedimen, tidak membahas faktor pengaruh berkurangnya air waduk dan hanya meninjau eksisting.

\section{METODOLOGI}

Pada penelitian ini digunakan metode studi literatur. Metode studi literatur adalah metode yang digunakan untuk mendapatkan kejelasan konsep dalam penelitian yaitu dengan mendapatkan bukubuku, jurnal maupun penelitian terdahulu yang berisikan dasar-dasar teori serta rumus-rumus perhitungan dan mendapatkan data yang mendukung dalam menyelesaikan penelitian ini.
Data tersebut yaitu data sekunder yang diperoleh langsung dari pihak yang terkait dengan penelitian ini. Data sekunder adalah sumber data penelitian yang diperoleh melalui media perantara atau secara tidak langsung yang berupa buku, catatan, bukti yang telah ada, atau arsip baik yang dipublikasi maupun tidak dipublikasikan secara umum. Adapun tahap-tahap dalam penelitian ini yaitu, menghitung debit andalan dan evaporasi, menghitung kapasitas daya tampung waduk, menghitung debit PLTA, menghitung water balance, menghitung daya listrik dan simulasi pola operasi PLTA.

Tahap 1. Menghitung debit andalan dan evaporasi.

Debit andalan adalah besarnya debit yang tersedia untuk memenuhi kebutuhan air dengan resiko kegagalan yang telah diperhitungkan. Analisis debit andalan bertujuan untuk menentukan debit perencanaan yang diharapkan selalu tersedia di sungai. Umumnya debit andalan diperhitungkan karena diperlukan pada perencanaan pengembangan air irigasi, air baku dan pembangkit listrik tenaga air, yaitu untuk menentukan persediaan air pada bangunan pengambilan (intake). Debit tersebut digunakan sebagai patokan ketersediaan debit yang masuk ke waduk pada saat pengoperasiannya [2].

Dalam menganalisa debit andalan, data dibuat berkelompok dengan menentukan kelas dan interval tiap kelas. Dalam menentukan kelas dan interval menggunakan cara statistik pegolahan data. Dari data debit dilihat jumlah kejadian dari suatu debit yang masuk interval, kemudian prosentase kumulatif dari kejadiannya disusun sehingga dapat diperoleh gambaran duration curve dari data tersebut [3]. Cara perhitungannya adalah menggunakan persamaan-persamaan berikut:

$\begin{array}{ll}R & =a \max -a \min \\ k & =1+3,3322 \log (n) \\ \text { Interval } & =\frac{R}{k}\end{array}$

Keterangan:

$\begin{array}{ll}\text { a } \min & =\text { nilai data terkecil } \\ \text { a max } & =\text { nilai data terbesar } \\ n & =\text { jumlah data yang diolah } \\ \mathrm{k} & =\text { banyaknya kelas interval } \\ \text { interval } & =\text { interval data untuk memasukkan data } \\ & \text { yang nantinya dihitung banyaknya } \\ & \text { dengan frekuensi }\end{array}$

Interval dimulai dari nilai data $\leq$ a min

$T=\frac{n}{m}$

$P=\frac{1}{T}=\frac{m}{n} \times 100 \%$

Keterangan:

$\mathrm{T}=$ masa ulang

$P$ = besarnya probabilitas $(\%)$

$m$ = nomor urut data

$n$ = jumlah data yang diolah 
Setelah diperoleh gambaran duration curve, maka debit andalan untuk PLTA saat ini (eksis) dapat ditentukan menggunakan persamaan berikut [4]:

$Q=\frac{V}{t}$

Keterangan:

$\begin{array}{ll}\mathrm{Q} & =\operatorname{Debit}\left(\mathrm{m}^{3} / \mathrm{det}\right) \\ \mathrm{V} & =\text { Volume } \operatorname{air}\left(\mathrm{m}^{3}\right) \\ \mathrm{t} & =\text { waktu }_{\text {detik }} \\ \text { Volume PLTA } & =\text { Volume }_{\text {waduk }}\end{array}$

Daya adalah kemampuan melakukan sesuatu atau kemampuan bertindak [5]. Daya listrik adalah kemampuan suatu peralatan listrik untuk melakukan usaha akibat adanya perubahan kerja dan perubahan muatan listrik tiap satuan waktu [6]. Untuk daerah tertentu pada daerah aliran sungai terdapat perbedaan tinggi pada sungai sebesar $\mathrm{H}$ meter, daya yang dapat dibangkitkan karena perbedaan tinggi ini [7] adalah sebesar:

$P=Q \rho g H(W a t t)=9,8 Q H(k W)$

Keterangan:

$Q=$ debit air $\left(\mathrm{m}^{3} /\right.$ detik $)$

$\rho=$ masa jenis air $=1000\left(\mathrm{~kg} / \mathrm{m}^{3}\right)$

$g$ = percepatan gaya berat $=9,8(\mathrm{~m} /$ detik $)$

$\mathrm{H}=$ perbedaan muka air $(\mathrm{m})$ atau tinggi jatuh efektif $(m)$

Evaporasi adalah proses penguapan air yang berada di permukaan bumi, baik itu air laut, air danau, air sungai, air pada permukaan tanah dan juga air yang ada pada permukaan tumbuhan akibat sinar matahari (evapotranspirasi) [8]. Hasil perhitungan evaporasi akan dimasukkan ke dalam tabel perhitungan water balance. Untuk analisa evaporasi dibutuhkan data temperatur, kelembaban relatif dan kecepatan angin. Yang mana data-data tersebut akan dikelompokkan berdasarkan ratarata bulanan lalu ditentukan nilai evaporasi bulanannya menggunakan rumus empiris Penman [9] pada persamaan:

$H=\frac{e}{E} \times 100$

Keterangan:

$\mathrm{H}=$ kelembaban relatif $(\%)$

$\mathrm{e}=$ tekanan uap pada waktu pengukuran (mb atau $\mathrm{mmHg}$ )

$\mathrm{E}=$ tekanan uap jenuh $(\mathrm{mb}$ atau $\mathrm{mmHg})$

Untuk mempermudah perhitungan, nilai tekanan uap jenuh (E) sebagai fungsi temperatur $\left({ }^{\circ} \mathrm{C}\right)$ ditunjukkan pada Tabel 1.

$E=0,35\left(e_{a}-e_{d}\right)\left(1+\frac{V}{100}\right)$

Keterangan:

$\mathrm{E}=$ evaporasi (mm/hari)

$e_{a}=$ tekanan uap jenuh pada suhu rata-rata harian (mmHg)

$e_{d}=$ tekanan uap sebenarnya(mmHg)

$\mathrm{V}=$ kecepatan angin pada ketinggian $2 \mathrm{~m}$ di atas permukaan tanah (mile/hari)

$1 \mathrm{mile}=1600 \mathrm{~m}$
Tabel 1. Nilai Tekanan Uap Jenuh

\begin{tabular}{cc}
\hline $0^{\circ}$ & $\mathrm{p}(\mathrm{mmHg})$ \\
\hline-60 & 0,0008 \\
-40 & 0,096 \\
-20 & 0,783 \\
-10 & 1,964 \\
-1 & 4,22 \\
0 (air + es + uap) & 4,58 \\
10 & 9,21 \\
20 & 17,55 \\
30 & 31,86 \\
40 & 55,4 \\
50 & 93,6 \\
60 & 149,6 \\
80 & 355,4 \\
100 & $760,0(1 \mathrm{~atm})$ \\
110 & 1074 \\
125 & 1740 \\
200 & 11650 \\
250 & 29770 \\
300 & 64300 \\
350 & 123710 \\
\hline
\end{tabular}

Sumber: Kiyotoka Mori dkk, 2006

Tahap 2. Menghitung kapasitas daya tampung waduk.

Berhubung fungsi utama dari waduk adalah untuk menyediakan tampungan, maka ciri fisiknya yang paling penting adalah kapasitas tampungan. Kapasitas waduk yang bentuknya beraturan dapat dihitung dengan rumus-rumus untuk menghitung volume benda padat [10]. Kapasitas tampungan waduk atau volume dari waduk dapat dihitung melalui kondisi topografinya. Penentuan volume dapat diketahui dengan melihat grafik hubungan antara luas genangan, elevasi, dan volume airnya. Tinggi (elevasi) dasar yang diambil adalah dasar sungai di tempat rencana as bendungan [11].

Adapun perhitungan kapasitas daya tampung waduk menggunakan metode mass curve dilakukan untuk menyesuaikan besar debit outflow PLTA dengan besar volume aktif waduk yang telah tersedia (eksis), sehingga besar volume debit outflow PLTA tidak melebihi volume aktif waduk [12]. Hasil dari perhitungan ini akan diplot kedalam suatu grafik mass curve.

Tahap 3. Menghitung debit PLTA.

Adapun perhitungan debit PLTA dilakukan untuk menentukan besar debit yang akan dikeluarkan waduk untuk memutar turbin agar dapat membangkitkan listrik pada generator PLTA [4]. Adapun debit yang dihasilkan akan dimasukkan ke dalam tabel perhitungan water balance.

Tahap 4. Menghitung water balance.

Dalam perhitungan water balance digunakan metode sequent peak analysis menggunakan rumus pada persamaan sebagai berikut [12]:

$K_{t}=Q F_{t a}+K_{t-1}-R_{t}$, jika positif

$K_{t} \quad=0$, jika negatif

Keterangan:

$K_{t} \quad=$ tampungan yang dapat disimpan dimana pada periode $\mathrm{t}=0$, nilai $K_{t}=0$

$R_{t} \quad=$ outflow

$K_{t-1}=$ tampungan yang dapat disimpan sebelum periode $t$ 
$Q F_{t a}=$ inflow dari tampungan

Untuk menghitung $Q F_{t a}$ digunakan
persamaan [12]:
$Q F_{t a}=Q F_{t}+P P_{t}-E V_{t}$
Keterangan:
$Q F_{t} \quad=$ debit dari sungai yang masuk tampungan
$P P_{t} \quad=$ presipitasi (hujan) yang jatuh di atas
$\quad$ tampungan
$E V_{t} \quad=$ evaporasi (penguapan) yang terjadi di
$\quad$ tampungan

Pada tabel water balance nilai $K_{t}$ yang merupakan volume tampungan tidak boleh bernilai negatif sehingga bila terjadi nilai negatif maka debit PLTA yang selanjutnya disebut debit outflow harus dirubah dengan cara coba-coba sehingga nilai $K_{t} \geq 0$. Apabila telah dicoba-coba nilai $K_{t}$ adalah nol maka untuk mendapatkan nilai debit outflow yang sesuai dapat menggunakan persamaan (10), persamaan (11) dan persamaan (12).

Tahap 5. Menghitung daya listrik.

Diketahuinya nilai debit outflow maka dapat dihitung besar daya listrik yang dihasilakan PLTA. Dalam perhitungannya digunakan rumus daya yang berhubungan dengan debit yang tunjukkan pada persamaan (7). Nilai daya yang didapatkan akan dihitung nilai harian, bulanan dan tahunannya pada tabel water balance.

Tahap 6. Simulasi pola operasi PLTA.

Operasi waduk (reservoir operation) adalah penampungan aliran air sungai ke dalam sebuah waduk (reservoir) dan pelepasan dari pada air yang telah ditampung tersebut untuk berbagai tujuan. Metode pengoperasian waduk untuk mendapatkan hasil yang optimal salah satunya dengan menerapkan simulasi pola operasi waduk [13]. Optimasi adalah operasi pemanfaatan sumber daya air yang optimal dengan aspek yang sangat penting dalam pendayagunaan sumber daya air khususnya pada perencanaan operasi waduk [14]. Dalam kasus lain optimal yaitu berbiaya terendah namun berfungsi maksimal [15].

Dalam permasalahan pendayagunaan sumber daya air, simulasi merupakan suatu teknik permodelan untuk menirukan perilaku suatu sistem ke dalam suatu model. Model simulasi digunakan untuk mengevaluasi apa yang akan terjadi di dalam sistem jika diberikan masukan-masukan tertentu. Dengan demikian pola pengelolaan sistem dapat dievaluasi dengan mempelajari perilaku sistem terhadap masukan berbagai skenario pada sistem [16].

Perhitungan optimasi dilakukan dengan model simulasi. Simulasi pengoperasian PLTA bertujuan untuk menghitung operasi waduk / PLTA pada periode tertentu dengan memperhatikan debit sungai sebagai input dari waduk dan debit PLTA sebagai debit output [12]. Dalam menentukan besar daya listrik yang dihasilkan ditentukan oleh besar debit andalan PLTA. Dalam menentukan besar debit tersebut digunakan cara coba-coba yaitu dengan mencari besar debit dari water balance debit andalan. Kemudian dihitung besar daya listrik dari debit tersebut. Dari hasil perhitungan dibuat grafik persen debit andalan (\%) vs daya yang dihasilkan (kW) sehingga dapat diketahui pola debit andalan terhadap daya listrik yang dihasilkan. Selanjutnya, dilakukan perbandingan antara daya listrik yang dihasilkan setelah dioptimalisasikan dengan daya listrik yang eksis sekarang. Pada tahap ini akan direncanakan daya maksimum generator sehingga dapat diketahui jumlah generator yang bekerja.

\section{HASIL DAN DISKUSI}

\section{Analisa Debit Andalan dan Evaporasi}

Debit andalan digunakan sebagai debit outflow pada tabel water balance. Dalam menganalisa debit andalan dibutuhkan data pengamatan debit selama periode tertentu. Semakin lama data pengamatan maka semakin bagus gambaran yang dihasilkan pada duration curve. Duration curve dapat digambarkan dari data debit inflow harian maupun dari data debit inflow bulanan.

Tabel 2. Prosentase Frekuensi Kumulatif Debit Inflow Harian

\begin{tabular}{|c|c|c|c|c|c|c|c|}
\hline \multirow{2}{*}{$\begin{array}{c}\begin{array}{c}\text { Kel } \\
\text { as }\end{array} \\
1\end{array}$} & \multicolumn{3}{|c|}{$\begin{array}{l}\text { Interval } \\
\left(\mathrm{m}^{3} / \mathrm{det}\right)\end{array}$} & \multirow{2}{*}{$\begin{array}{c}\begin{array}{c}\text { Titik } \\
\text { Tengah } \\
\left(\mathbf{m}^{3} / \mathbf{d e t}\right. \\
\text { ) }\end{array} \\
69.71\end{array}$} & \multirow{2}{*}{$\begin{array}{c}\begin{array}{c}\text { Freku } \\
\text { ensi }\end{array} \\
2002\end{array}$} & \multirow{2}{*}{$\begin{array}{c}\begin{array}{c}\text { Freku } \\
\text { ensi } \\
\text { Kumul } \\
\text { atif }\end{array} \\
3652\end{array}$} & \multirow{2}{*}{$\begin{array}{c}\begin{array}{c}\text { Prosen } \\
\text { tase }\end{array} \\
(\%)\end{array}$} \\
\hline & $\begin{array}{c}64.7 \\
8\end{array}$ & - & $\begin{array}{c}204 . \\
21\end{array}$ & & & & \\
\hline 2 & $\begin{array}{c}204 . \\
31\end{array}$ & - & $\begin{array}{c}473 . \\
21\end{array}$ & 338.76 & 1278 & 1650 & 45.18 \\
\hline 3 & $\begin{array}{l}473 . \\
315\end{array}$ & - & $\begin{array}{c}742 . \\
21\end{array}$ & 607.76 & 275 & 372 & 10.18 \\
\hline 4 & $\begin{array}{c}742 . \\
315\end{array}$ & - & $\begin{array}{c}1011 \\
.21\end{array}$ & 876.76 & 56 & 97 & 2.65 \\
\hline 5 & $\begin{array}{c}1011 \\
.31\end{array}$ & - & $\begin{array}{c}1280 \\
.21\end{array}$ & 1145.76 & 25 & 41 & 1.12 \\
\hline 6 & $\begin{array}{c}1280 \\
.31\end{array}$ & & $\begin{array}{c}1549 \\
.21\end{array}$ & 1414.76 & 9 & 16 & 0.43 \\
\hline 7 & $\begin{array}{c}1549 \\
.31\end{array}$ & & $\begin{array}{c}1818 \\
.21\end{array}$ & 1683.76 & 3 & 7 & 0.19 \\
\hline 8 & $\begin{array}{c}1818 \\
.31\end{array}$ & & $\begin{array}{c}2087 \\
.21\end{array}$ & 1952.76 & 2 & 4 & 0.11 \\
\hline 9 & $\begin{array}{c}2087 \\
.31\end{array}$ & & $\begin{array}{c}2356 \\
.21\end{array}$ & 2221.76 & 1 & 2 & 0.05 \\
\hline 10 & $\begin{array}{c}2356 \\
.31\end{array}$ & & $\begin{array}{c}2625 \\
.21\end{array}$ & 2490.76 & 0 & 1 & 0.02 \\
\hline 11 & $\begin{array}{c}2625 \\
.31\end{array}$ & - & $\begin{array}{c}2894 \\
.21\end{array}$ & 2759.76 & 0 & 1 & 0.02 \\
\hline 12 & $\begin{array}{c}2894 \\
.31\end{array}$ & - & $\begin{array}{c}3163 \\
.21\end{array}$ & 3028.76 & 0 & 1 & 0.02 \\
\hline 13 & $\begin{array}{c}3163 \\
.31\end{array}$ & - & $\begin{array}{c}3432 \\
.21\end{array}$ & 3297.76 & 1 & 1 & 0.02 \\
\hline
\end{tabular}

Berdasarkan data debit inflow tersebut dapat ditentukan prosentase frekuensi kumulatif debit inflow. Hasil dari prosentase tersebut akan diplot ke dalam sebuah duration curve. Adapun prosentase frekuensi kumulatif debit inflow harian selama periode 10 tahun yang didapatkan dari perhitungan debit andalan dapat dilihat pada tabel 2 .

Berdasarkan tabel tersebut terlihat frekuensi pada kolom 4 yang merupakan jumlah data yang berada dalam interval setiap kelas. Pada interval data antara $(-64,785) \mathrm{m}^{3} /$ det hingga 204,215 $\mathrm{m}^{3} /$ det memiliki jumlah data sebanyak 2002 data. 
Nilai frekuensi kumulatif pada kelas 1 yaitu 3652 yang merupakan jumlah keseluruhan data debit inflow harian selama 10 tahun. Sedangkan nilai frekuensi kumulatif pada kelas 2 yaitu 1650 didapatkan dari pengurangan 3652 dengan 2002 yang merupakan nilai frekuensi pada kolom 4 . Nilai prosentase kelas 1 adalah $100 \%$ artinya debit $69,715 \mathrm{~m}^{3}$ /det memiliki prosentase kejadian $100 \%$ dalam 1 tahun. Adapun duration curve yang dihasilkan dari data debit inflow harian selama periode 10 tahun yang didapatkan dari Tabel 1 dapat dilihat pada gambar berikut.

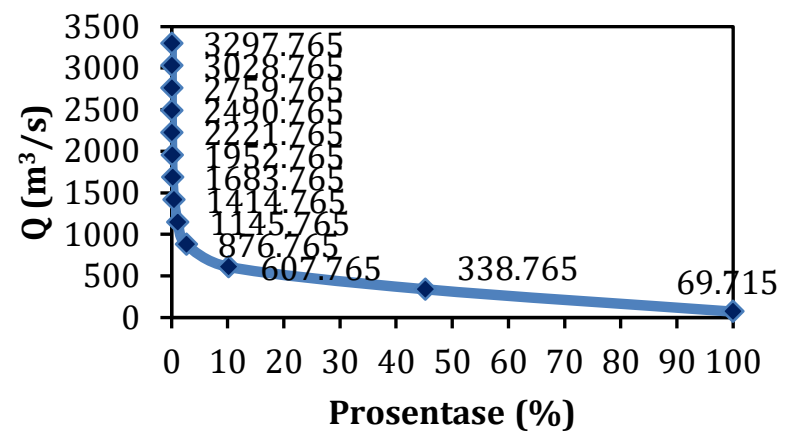

Gambar 2. Duration Curve dari Data Harian

Dari Gambar 2 terlihat grafik hubungan prosentase $(\%)$ dan $Q\left(\mathrm{~m}^{3} / \mathrm{s}\right)$. Prosentase yang dimaksud pada grafik adalah frekuensi kejadian dari suatu besaran debit yang digambarkan dalam suatu periode pengamatan. Sedangkan Q merupakan debit sungai. Prosentase $100 \%$ artinya debit sungai terjadi selama 365 hari dalam 1 tahun. Gambar 2 menunjukkan semakin besar prosentase kejadian suatu debit dalam satu tahun maka semakin kecil debit yang tersedia begitu sebaliknya. Hal ini ditunjukkan pada prosentase $45 \%$ hingga $100 \%$ nilai debit turun tidak terlalu signifikan sedangkan pada prosentase $10 \%$ hingga $100 \%$ turunnya cukup signifikan.

Debit andalan juga bisa dianalisa menggunakan data debit bulanan yang didapat dari hasil rata-rata debit harian perbulannya selama periode 10 tahun. Adapun prosentase frekuensi kumulatif debit inflow bulanan selama periode 10 tahun dapat dilihat pada tabel berikut.

Tabel 3. Prosentase Frekuensi Kumulatif Debit Inflow Bulanan

\begin{tabular}{|c|c|c|c|c|c|c|c|}
\hline \multirow{2}{*}{$\begin{array}{c}\begin{array}{c}\text { Kel } \\
\text { as }\end{array} \\
1\end{array}$} & \multicolumn{3}{|c|}{$\begin{array}{l}\text { Interval } \\
\left(\mathrm{m}^{3} / \mathrm{det}\right)\end{array}$} & \multirow{2}{*}{$\begin{array}{c}\begin{array}{c}\text { Titik } \\
\text { Tengah } \\
\text { (m³ } / \mathbf{d e t})\end{array} \\
82.79\end{array}$} & \multirow{2}{*}{$\begin{array}{c}\begin{array}{c}\text { Freku } \\
\text { ensi }\end{array} \\
29\end{array}$} & \multirow{2}{*}{$\begin{array}{c}\begin{array}{c}\text { Freku } \\
\text { ensi } \\
\text { Kumul } \\
\text { atif }\end{array} \\
120\end{array}$} & \multirow{2}{*}{$\begin{array}{c}\begin{array}{c}\text { Prosen } \\
\text { tase } \\
(\%)\end{array} \\
\begin{array}{c}100.00 \\
0\end{array}\end{array}$} \\
\hline & $\begin{array}{c}32.2 \\
9\end{array}$ & & $\begin{array}{l}133 . \\
292\end{array}$ & & & & \\
\hline 2 & $\begin{array}{r}133 . \\
392\end{array}$ & & $\begin{array}{l}234 . \\
292\end{array}$ & 183.84 & 39 & 91 & 75.833 \\
\hline 3 & $\begin{array}{r}234 . \\
392\end{array}$ & & $\begin{array}{l}335 . \\
292\end{array}$ & 284.84 & 32 & 52 & 43.333 \\
\hline 4 & $\begin{array}{r}335 . \\
392\end{array}$ & & $\begin{array}{l}436 . \\
292\end{array}$ & 385.84 & 6 & 20 & 16.667 \\
\hline 5 & $\begin{array}{l}436 \\
392\end{array}$ & & $\begin{array}{l}537 . \\
292\end{array}$ & 486.84 & 8 & 14 & 11.667 \\
\hline 6 & $\begin{array}{r}537 . \\
392\end{array}$ & & $\begin{array}{l}638 . \\
292\end{array}$ & 587.84 & 5 & 6 & 5.000 \\
\hline 7 & $\begin{array}{r}638 \\
392\end{array}$ & & $\begin{array}{l}739 . \\
292\end{array}$ & 688.84 & 0 & 1 & 0.833 \\
\hline 8 & $\begin{array}{r}739 . \\
392 \\
\end{array}$ & . & $\begin{array}{l}840 . \\
292\end{array}$ & 789.84 & 1 & 1 & 0.833 \\
\hline
\end{tabular}

Berdasarkan Tabel 3 terlihat titik tengah $82,79 \mathrm{~m}^{3} /$ det yang merupakan nilai debit inflow pada interval data antara $32,29 \mathrm{~m}^{3} /$ det hingga 133,292 $\mathrm{m}^{3} /$ det. Frekuensi pada kolom 4 adalah jumlah data yang berada dalam interval setiap kelas. Pada interval data antara 32,29 $\mathrm{m}^{3} /$ det hingga 133,292 $\mathrm{m}^{3} /$ det memiliki jumlah data sebanyak 29 data. Nilai frekuensi kumulatif pada kelas 1 yaitu 120 yang merupakan jumlah keseluruhan data debit inflow bulanan selama 10 tahun. Sedangkan nilai frekuensi kumulatif pada kelas 2 yaitu 91 didapatkan dari pengurangan 120 dengan 29 yang merupakan nilai frekuensi pada kolom 4. Nilai prosentase kelas 1 adalah $100 \%$ artinya debit $82,79 \mathrm{~m}^{3} /$ det memiliki prosentase kejadian $100 \%$ dalam 1 tahun. Duration curve yang dihasilkan dari data bulanan debit inflow selama periode 10 tahun dapat dilihat pada Gambar 3 berikut.

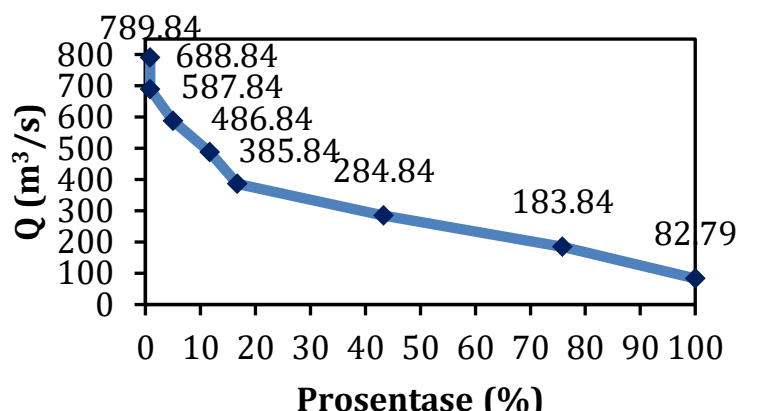

Gambar 3. Duration Curve dari Data Bulanan

Gambar 3 merupakan grafik yang menunjukkan hubungan prosentase (\%) dan Q $\left(\mathrm{m}^{3} / \mathrm{s}\right)$ sama dengan Gambar 3. Gambaran grafik yang dihasilkan dari Gambar 3 sama dengan Gambar 2 yaitu semakin besar prosentase kejadian suatu debit dalam satu tahun maka semakin kecil debit yang tersedia begitu sebaliknya. Terlihat pada prosentase $75 \%$ hingga $100 \%$ nilai debit turun tidak terlalu signifikan sedangkan pada prosentase $40 \%$ hingga $100 \%$ turunnya cukup signifikan. Duration curve dari data harian mendapatkan hasil yang lebih detail dibandingkan dengan duration curve dari data bulanan.

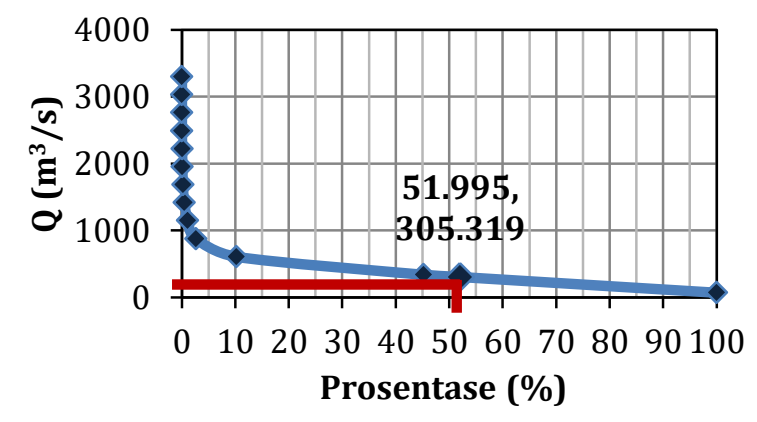

Gambar 4. Duration Curve dari Debit
Andalan PLTA Eksis

Berdasarkan analisa debit andalan PLTA Koto Panjang saat ini (eksis) didapatkan debit 
andalan sebesar 305,319 $\mathrm{m}^{3} /$ det. Debit 305,319 $\mathrm{m}^{3} /$ det dengan intervolasi didapatkan prosentasenya pada duration curve adalah sebesar $51,995 \%$ dapat dilihat pada gambar 4 berikut ini.

Pada Gambar 4 terlihat duration curve dari data harian dan garis merah pada grafik yang menunjukkan nilai prosentase dan debit andalan PLTA Koto Panjang saat ini. Debit andalan yang didapatkan adalah sebesar 305,319 $\mathrm{m}^{3} /$ det yang memiliki prosentase 51,995 \%. Artinya debit $305,319 \mathrm{~m}^{3} /$ det terjadi selama $\frac{51,995}{100} \times 365$ hari yaitu 189,782 hari dalam 1 tahun.

Adapun dalam menganalisa evaporasi dibutuhkan data klimatologi seperti data suhu, kelembaban, kecepatan angin dan tekanan atmosfir. Pada Tabel 4 dapat dilihat nilai evaporasi pada tahun 2010 hingga 2019. Dari Tabel 4 dapat dilihat hasil analisa evaporasi dari tahun 2010 hingga tahun 2019. Nilai evaporasi dihitung perbulannya menggunakan rumus empiris Penman pada persamaan (8) dan (9) dari bulan januari hingga bulan desember selama 10 tahun mengikuti jumlah tahun dari data debit inflow harian.

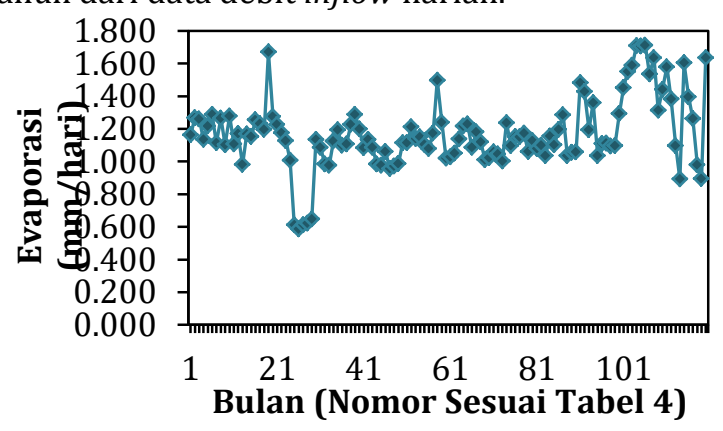

Gambar 5. Hasil Analisa Evaporasi

Tabel 4. Hasil Analisa Evaporasi

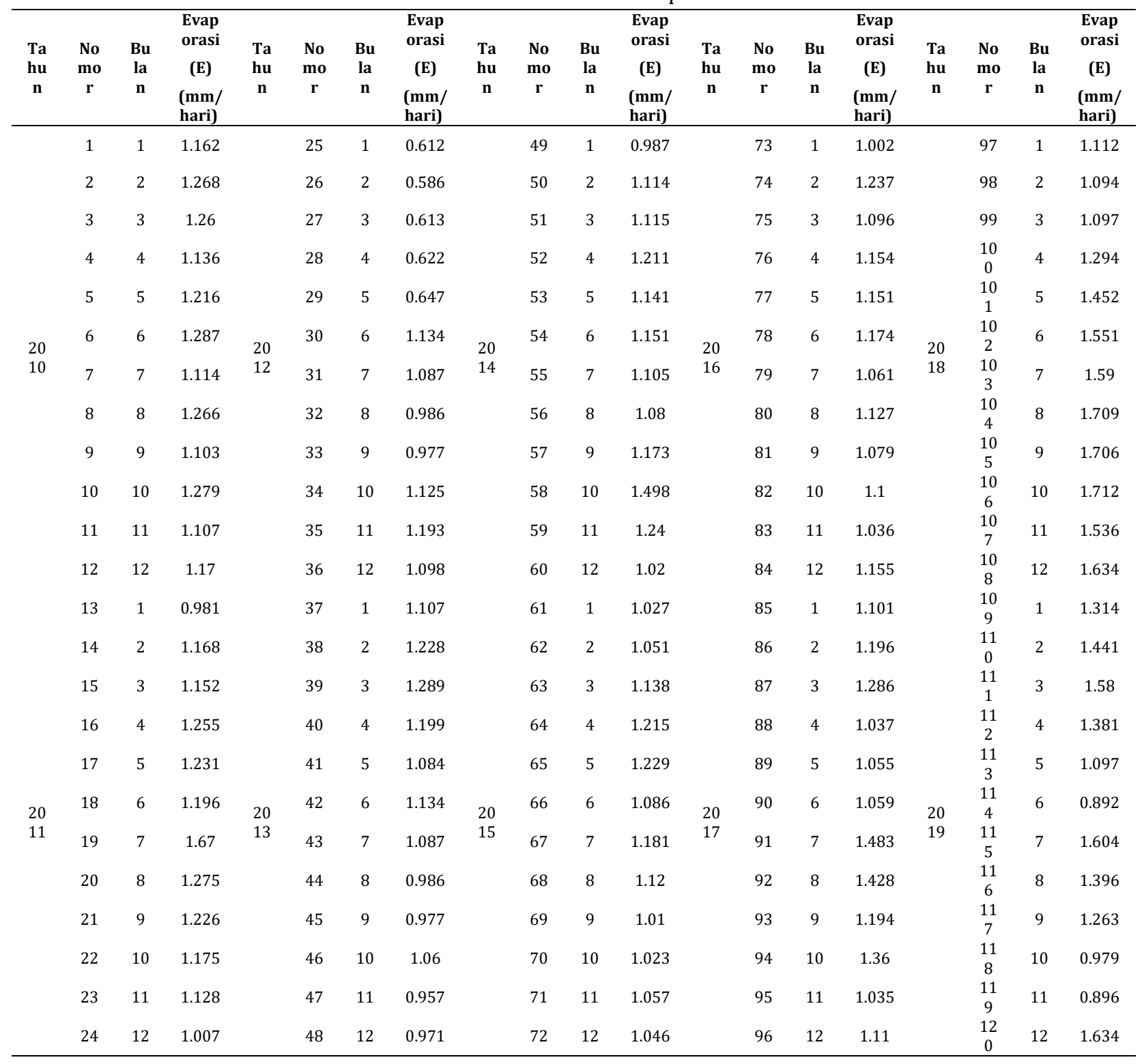

Nilai evaporasi ini berbeda-beda tiap bulannya tergantung dari nilai suhu, kelembaban, kecepatan angin dan tekanan atmosfir. Untuk lebih jelasnya dapat dilihat pada Gambar 5. 
Gambar 5 merupakan grafik hasil analisa evaporasi berdasarkan Tabel 3. Pada gambar terlihat perbedaan nilai evaporasi setiap bulannya selama 10 tahun. Rata-rata nilai evaporasi dalam 10 tahun yaitu lebih besar dari $0,8 \mathrm{~mm} /$ hari dan kurang dari 1,4 mm/hari. Nilai evaporasi bulan 90 hingga bulan 120 menunjukkan perbedaan turun naik yang cukup signifikan dibandingkan dengan bulan-bulan yang lain. Terlihat nilai evaporasi tertinggi yaitu 1,712 mm/hari pada bulan 106 yaitu bulan oktober tahun 2018. Sedangkan nilai evaporasi terendah yaitu $0,586 \mathrm{~mm} /$ hari pada bulan 26 yaitu bulan februari tahun 2012 .

\section{Analisa Kapasitas Daya Tampung Waduk}

Dalam pengoperasiannya, PLTA Koto Panjang bekerja selama 24 jam. Dalam melakukan analisa kapasitas daya tampung waduk metode yang digunakan adalah metode mass curve. Adapun pada jam ke 24 besar volume kumulatif pada analisa mass curve ini harus sama nilainya dengan volume efektif waduk agar volume outflow PLTA yang dihasilkan tidak melebihi volume efektif waduk. Dalam perhitungannya volume efektif yang diambil adalah volume dari elevasi 80,5 hingga 80,8 mdpl yaitu sebesar $33.217 .800 \mathrm{~m}^{3}$. Didapatkan debit sebesar $384,465 \mathrm{~m}^{3} /$ det sebagaimana terlihat pada Tabel 5.

Pada Tabel 5 terlihat $\mathrm{Q}$ yang merupakan debit yang akan digunakan sebagai debit outflow pada tabel water balance setelah dioptimalisasikan. Volume pada tabel merupakan volume yang dihasilkan oleh Q dalam satu jam selama 24 jam karena PLTA Koto Panjang bekerja selama 24 jam. Volume kumulatif yang dihasilkan pada jam ke 24 adalah volume efektif Waduk PLTA Koto Panjang. Dari penyesuaian nilai volume kumulatif pada jam ke 24 dengan volume efektif Waduk PLTA Koto Panjang maka didapatkan nilai Q yaitu 384,465 $\mathrm{m}^{3} /$ det. Dalam duration curve debit 384,465 $\mathrm{m}^{3} / \mathrm{det}$ merupakan debit 39,235 \%. Prosentase tersebut dapat dilihat pada Gambar 6.

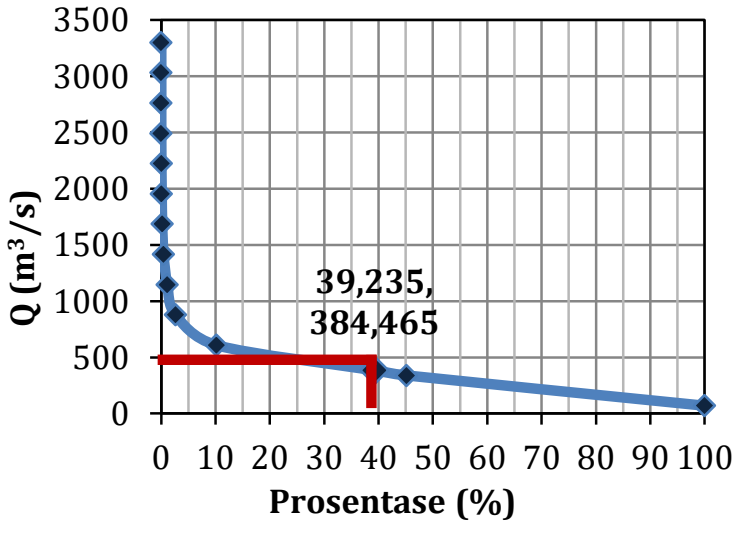

Gambar 6. Duration Curve dari Debit Hasil Analisa Mass Curve
Pada Gambar 6 terlihat duration curve dari data harian dan garis merah pada grafik menunjukkan nilai prosentase dan debit yang didapat dari perhitungan mass curve. Debit yang dihasilkan dari analisa mass curve adalah 384,465 $\mathrm{m}^{3} / \mathrm{s}$. Debit tersebut didapatkan prosentasenya pada duration curve sebesar 39,235 \%. Artinya debit 384,465 m³ $/ \mathrm{s}$ terjadi selama $\frac{39,235}{100} \times 365$ hari yaitu 143,208 hari dalam 1 tahun. Adapun mass curve yang dihasilkan dapat dilihat pada Gambar 7 berikut.

Tabel 5. Perhitungan Mass Curve

\begin{tabular}{|c|c|c|c|}
\hline Jam Ke & $\begin{array}{c}\mathbf{Q} \\
\mathbf{m}^{3} / \text { det }\end{array}$ & $\begin{array}{c}\text { Volume } \\
\mathrm{m}^{3}\end{array}$ & $\begin{array}{c}\text { Volume Kumulatif } \\
\qquad \mathbf{m}^{3}\end{array}$ \\
\hline 1 & 2 & 3 & 4 \\
\hline 0 & 384.465 & 0 & 0 \\
\hline 1 & 384.465 & 1.384 .075 .00 & 1.384 .075 .00 \\
\hline 2 & 384.465 & 1.384 .075 .00 & 2.768 .150 .00 \\
\hline 3 & 384.465 & 1.384 .075 .00 & 4.152 .225 .00 \\
\hline 4 & 384.465 & 1.384 .075 .00 & 5.536 .300 .00 \\
\hline 5 & 384.465 & 1.384 .075 .00 & 6.920 .375 .00 \\
\hline 6 & 384.465 & 1.384 .075 .00 & 8.304 .450 .00 \\
\hline 7 & 384.465 & 1.384 .075 .00 & 9.688 .525 .00 \\
\hline 8 & 384.465 & 1.384 .075 .00 & 11.072 .600 .00 \\
\hline 9 & 384.465 & 1.384 .075 .00 & 12.456 .675 .00 \\
\hline 10 & 384.465 & 1.384 .075 .00 & 13.840 .750 .00 \\
\hline 11 & 384.465 & 1.384 .075 .00 & 15.224 .825 .00 \\
\hline 12 & 384.465 & 1.384 .075 .00 & 16.608 .900 .00 \\
\hline 13 & 384.465 & 1.384 .075 .00 & 17.992 .975 .00 \\
\hline 14 & 384.465 & 1.384 .075 .00 & 19.377 .050 .00 \\
\hline 15 & 384.465 & 1.384 .075 .00 & 20.761 .125 .00 \\
\hline 16 & 384.465 & 1.384 .075 .00 & 22.145 .200 .00 \\
\hline 17 & 384.465 & 1.384 .075 .00 & 23.529 .275 .00 \\
\hline 18 & 384.465 & 1.384 .075 .00 & 24.913 .350 .00 \\
\hline 19 & 384.465 & 1.384 .075 .00 & 26.297 .425 .00 \\
\hline 20 & 384.465 & 1.384 .075 .00 & 27.681 .500 .00 \\
\hline 21 & 384.465 & 1.384 .075 .00 & 29.065 .575 .00 \\
\hline 22 & 384.465 & 1.384 .075 .00 & 30.449 .650 .00 \\
\hline 23 & 384.465 & 1.384 .075 .00 & 31.833 .725 .00 \\
\hline 24 & 384.465 & 1.384 .075 .00 & 33.217 .800 \\
\hline
\end{tabular}

Dari Gambar 7 terlihat jam dan volume berbanding lurus artinya semakin lama durasi waktunya maka volumenya akan semakin bertambah. Pada gambar Mass Curve diatas terlihat juga grafiknya berbentuk linier artinya terjadi penambahan volume setiap jamnya. Adapun yang dimaksud dengan volume ini adalah volume yang dihasilkan dari debit yang akan digunakan untuk debit PLTA. 


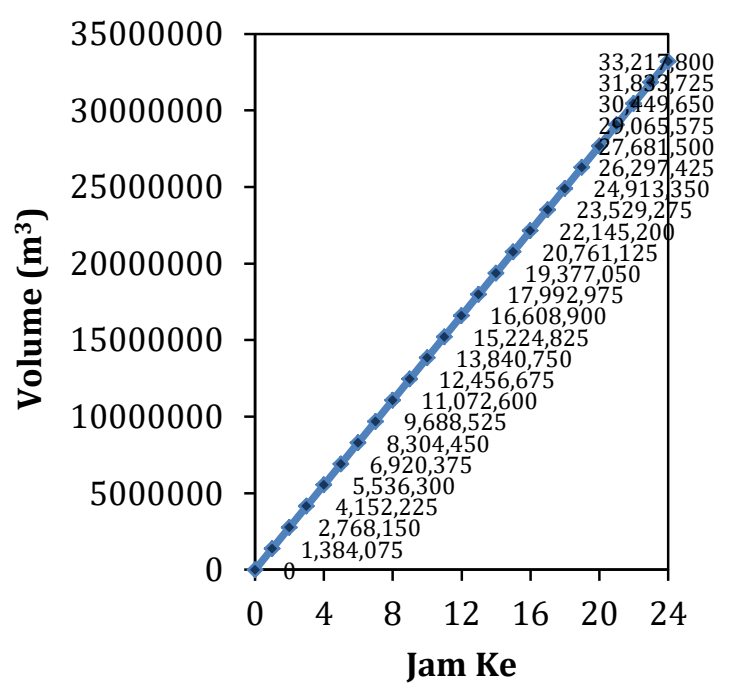

Gambar 7. Mass Curve

\section{Debit PLTA}

Debit PLTA merupakan debit outflow dari waduk yang digunakan untuk memutar turbin sehingga menghasilkan listrik dengan bantuan generator. Debit yang digunakan sebagai debit PLTA adalah debit yang dihasilkan dari analisa Mass Curve. Hal ini dikarenakan PLTA beroperasi selama 24 jam sehingga turbin yang diputar oleh debit outflow PLTA juga beroperasi selama 24 jam. Maka berdasarkan hasil analisa Mass Curve didapatkan debit PLTA adalah sebesar 384,465 m³/det.

\section{Analisa Water Balance, Daya Listrik dan Simulasi PLTA}

Simulasi pengoperasian PLTA bertujuan untuk menghitung operasi waduk / PLTA pada periode tertentu dengan memperhatikan debit sungai sebagai input dari waduk dan debit PLTA sebagai debit output. Dari perhitungan water balance sebelum dan setelah dioptimalisasi dapat diketahui bahwa daya yang dihasilkan PLTA sebelum dioptimalisasikan adalah 13.302,315 kWatt pada musim kering dan 114.000 kWatt pada musim hujan. Sedangkan daya setelah dioptimalisasikan adalah 13.302,315 kWatt pada musim kering dan 143.551,645 kWatt pada musim hujan. Untuk lebih jelasnya dapat dilihat pada Tabel 6 yaitu tabel water balance untuk tahun 2010 setelah dioptimalisasikan dan Tabel 7 yaitu tabel water balance untuk tahun 2010 sebelum dioptimalisasikan.

Pada Tabel 6 terlihat Kt yang merupakan tampungan yang dapat disimpan dimana pada periode $\mathrm{t}=0$ nilai $K_{t}=0$ atau dapat dikatakan sebagai volume tampungan atau volume berlebih dalam sehari akibat volume inflow lebih besar dari volume outflow dan $\mathrm{P}$ adalah daya yang dapat dibangkitkan.

Tabel 6. Water Balance Setelah Dioptimalisasi

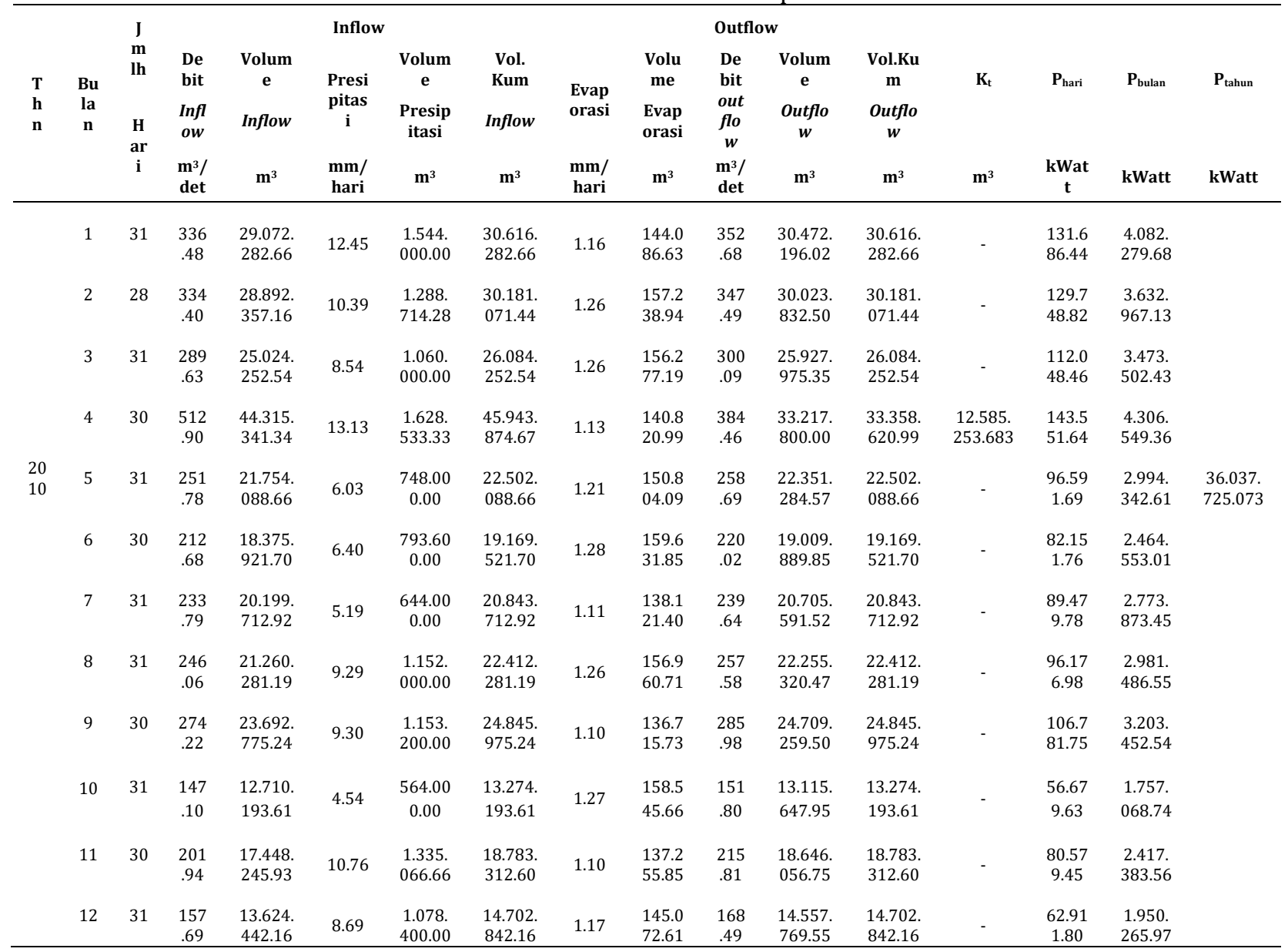


Berdasarkan Tabel 6 pada bulan Januari 2010 didapatkan nilai debit outflow sebesar $352,687 \mathrm{~m}^{3} /$ det yang merupakan hasil penyesuaian agar Kt $\geq 0$. Begitu juga dengan bulan-bulan seterusnya, jika debit andalan hasil analisa mass curve yang digunakan sebagai debit outflow dan menyebabkan nilai volume total outflow lebih besar dari nilai volume total inflow yang mana $\mathrm{Kt}$ akan bernilai negatif. Sedangkan dalam metode sequent peak analysis nilai Kt tidak boleh bernilai negatif. Maka debit outflow harus diperkecil agar nilai Kt $\geq 0$ dengan cara optimalisasi yaitu menyesuaikan debit outflow dengan volume air yang ada pada storage saat itu yaitu volume total inflow yang dikurangi volume evaporasi.
Kt ada yang tidak bernilai nol pada Tabel 6 yaitu pada bulan April 2010. Hal ini dikarenakan volume inflow lebih besar dibandingkan dengan volume outflow. Sehingga debit outflow yang digunakan adalah debit andalan hasil analisa mass curve yaitu 384,465 $\mathrm{m}^{3} /$ det. Adapun tabel water balance untuk tahun 2010 sebelum dioptimalisasikan dapat dilihat pada Tabel 7.

Terdapat perbedaan tabel water balance setelah dioptimalisasi dengan tabel water balance sebelum dioptimalisasi yaitu debit outflow yang digunakan. Debit outflow didapatkan dari hasil perhitungan debit andalan.

Tabel 7. Water Balance Sebelum Dioptimalisasi

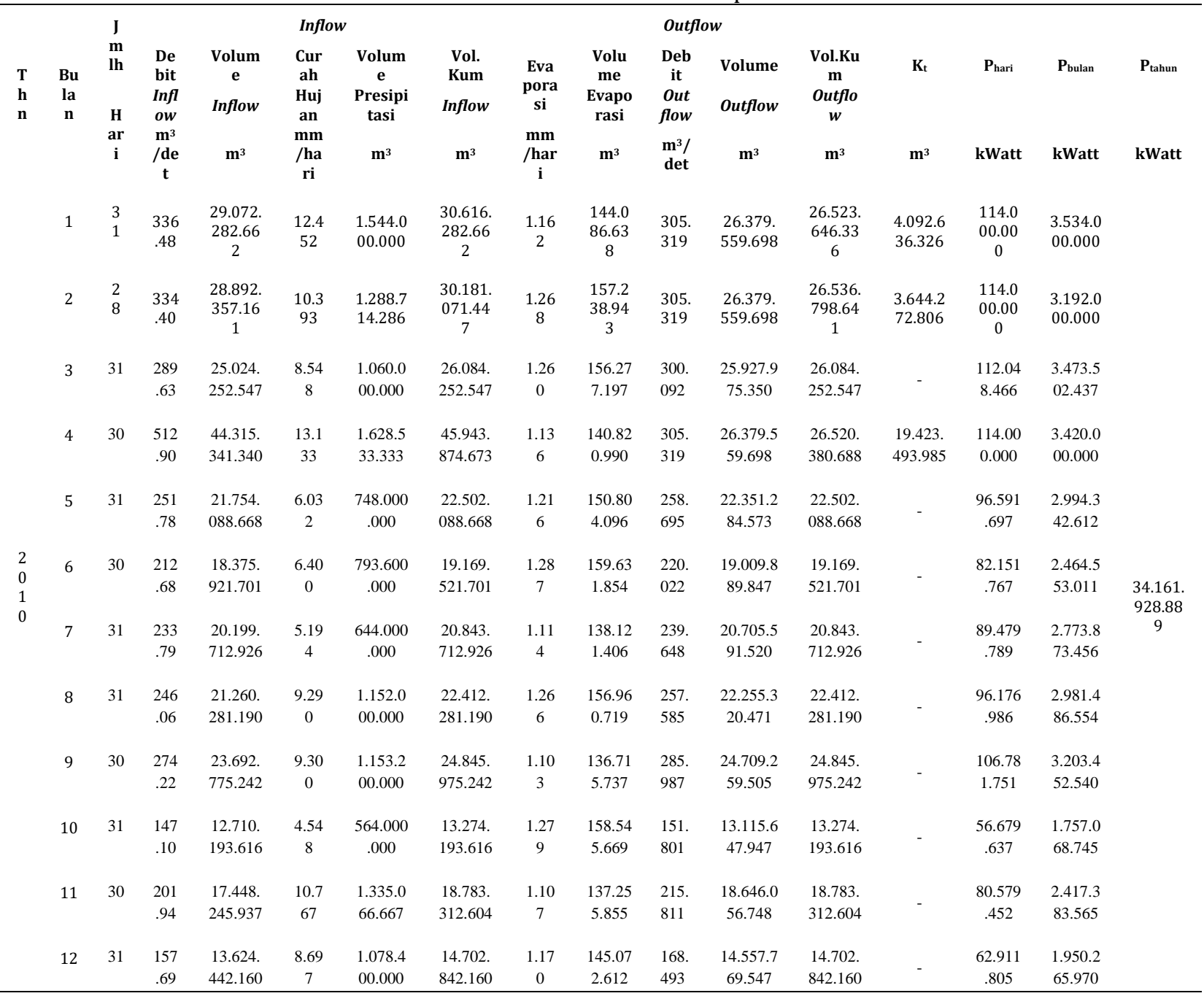

Sebelum dioptimalisasikan, debit andalan PLTA Koto Panjang adalah 305,319 m³/det yang didapatkan dari hasil perhitungan debit andalan PLTA eksis. Sedangkan setelah dioptimalisasikan, debit andalan yang digunakan adalah debit hasil analisa mass curve. Analisa mass curve menggunakan volume waduk aktif PLTA Koto panjang dalam perhitungannya.

Akibat perbedaan debit outflow tersebut maka volume outflow, volume total outflow dan daya yang dihasilkan setelah dioptimalisasi dengan sebelum dioptimalisasi juga akan berbeda. Kt ada yang bernilai nol karena volume total outflow lebih besar dari volume total inflow. Maka perlu dilakukan penyesuaian debit outflow agar $\mathrm{Kt} \geq 0$. Pada bulan Maret 2010 terlihat debit outflow sebesar 300,092 $\mathrm{m}^{3} /$ det yang merupakan hasil penyesuaian debit outflow dengan volume air yang ada pada storage saat itu yaitu volume total inflow dikurangi dengan volume evaporasi.

Pada Tabel 7 diatas terlihat pada bulan Januari $2010 \mathrm{Kt}$ tidak bernilai nol. Hal ini 
dikarenakan volume inflow lebih besar dibandingkan dengan volume outflow. Sehingga debit outflow yang digunakan adalah debit andalan PLTA eksis yaitu $305,319 \mathrm{~m}^{3} /$ det.

Berdasarkan tabel water balance dapat diketahui besar debit outflow PLTA yang didapat dari debit andalan yang mana debit tersebut digunakan untuk menghasilkan daya listrik. Adapun hubungan prosentase debit andalan dengan daya listrik dapat dilihat pada Tabel 8 dan Gambar 8.

Tabel 8. Persen Debit Andalan (\%) Vs Daya Listrik (kWatt)

\begin{tabular}{|c|c|c|c|c|c|c|c|c|c|c|c|c|c|}
\hline \multirow{2}{*}{$\begin{array}{l}\text { Tahun } \\
\text { Debit }\end{array}$} & \multicolumn{13}{|c|}{ Daya Rata-Rata yang Dihasilkan per Hari Sesuai \% Debit Duration Curve (K Watt) } \\
\hline & 35 & 37 & 39 & 41 & 43 & 45 & 47 & 49 & 51 & 53 & 55 & 57 & 59 \\
\hline 2010 & $\begin{array}{c}100.045 \\
.394\end{array}$ & $\begin{array}{c}99.567 . \\
038\end{array}$ & $\begin{array}{c}99.088 . \\
681\end{array}$ & $\begin{array}{c}98.610 . \\
324\end{array}$ & $\begin{array}{c}98.131 . \\
967\end{array}$ & $\begin{array}{c}97.035 . \\
122\end{array}$ & $\begin{array}{c}96.071 . \\
977\end{array}$ & $\begin{array}{c}95.155 . \\
713\end{array}$ & $\begin{array}{c}94.239 \\
449\end{array}$ & $\begin{array}{c}93.323 . \\
185\end{array}$ & $\begin{array}{c}92.110 . \\
706\end{array}$ & $\begin{array}{c}90.726 . \\
278\end{array}$ & $\begin{array}{c}89.199 . \\
171\end{array}$ \\
\hline 2011 & $\begin{array}{c}96.358 . \\
095\end{array}$ & $\begin{array}{c}95.401 \\
382\end{array}$ & $\begin{array}{c}94.444 . \\
668\end{array}$ & $\begin{array}{c}93.487 . \\
954\end{array}$ & $\begin{array}{c}92.176 \\
133\end{array}$ & $\begin{array}{c}90.741 . \\
063\end{array}$ & $\begin{array}{c}89.777 . \\
919\end{array}$ & $\begin{array}{c}88.842 . \\
238\end{array}$ & $\begin{array}{c}87.330 \\
933\end{array}$ & $\begin{array}{c}85.803 . \\
826\end{array}$ & $\begin{array}{c}84.276 . \\
719\end{array}$ & $\begin{array}{c}82.506 . \\
950\end{array}$ & $\begin{array}{c}80.369 \\
000\end{array}$ \\
\hline 2012 & $\begin{array}{c}82.856 . \\
303\end{array}$ & $\begin{array}{c}81.899 . \\
590\end{array}$ & $\begin{array}{c}80.942 . \\
876\end{array}$ & $\begin{array}{c}79.986 . \\
162\end{array}$ & $\begin{array}{c}79.029 \\
449\end{array}$ & $\begin{array}{c}78.072 . \\
735\end{array}$ & $\begin{array}{c}77.430 \\
639\end{array}$ & $\begin{array}{c}76.819 \\
796\end{array}$ & $\begin{array}{c}76.168 . \\
752\end{array}$ & $\begin{array}{c}75.252 \\
488\end{array}$ & $\begin{array}{c}74.336 . \\
224\end{array}$ & $\begin{array}{c}73.419 . \\
960\end{array}$ & $\begin{array}{c}40.316 \\
889\end{array}$ \\
\hline 2013 & $\begin{array}{c}86.553 . \\
768\end{array}$ & $\begin{array}{c}86.075 \\
411\end{array}$ & $\begin{array}{c}85.597 . \\
054\end{array}$ & $\begin{array}{c}85.118 . \\
697\end{array}$ & $\begin{array}{c}84.200 \\
692\end{array}$ & $\begin{array}{c}83.243 . \\
978\end{array}$ & $\begin{array}{c}82.397 . \\
062\end{array}$ & $\begin{array}{c}81.480 . \\
798\end{array}$ & $\begin{array}{c}80.564 \\
534\end{array}$ & $\begin{array}{c}79.648 . \\
269\end{array}$ & $\begin{array}{c}78.510 \\
898\end{array}$ & $\begin{array}{c}77.289 \\
212\end{array}$ & $\begin{array}{c}76.067 \\
527\end{array}$ \\
\hline 2014 & $\begin{array}{c}77.433 . \\
310\end{array}$ & $\begin{array}{c}76.954 . \\
953\end{array}$ & $\begin{array}{c}76.476 . \\
596\end{array}$ & $\begin{array}{c}75.998 . \\
239\end{array}$ & $\begin{array}{c}74.903 \\
449\end{array}$ & $\begin{array}{c}73.946 . \\
736\end{array}$ & $\begin{array}{c}73.304 \\
640\end{array}$ & $\begin{array}{c}72.669 \\
841\end{array}$ & $\begin{array}{c}71.753 . \\
577\end{array}$ & $\begin{array}{c}70.837 . \\
312\end{array}$ & $\begin{array}{c}69.921 \\
048\end{array}$ & $\begin{array}{c}69.004 \\
784\end{array}$ & $\begin{array}{c}68.088 \\
520\end{array}$ \\
\hline 2015 & $\begin{array}{c}86.429 . \\
737\end{array}$ & $\begin{array}{c}85.473 . \\
024\end{array}$ & $\begin{array}{c}84.516 . \\
310\end{array}$ & $\begin{array}{c}83.559 . \\
596\end{array}$ & $\begin{array}{c}82.602 \\
883\end{array}$ & $\begin{array}{c}81.646 . \\
169\end{array}$ & $\begin{array}{c}80.780 . \\
567\end{array}$ & $\begin{array}{c}79.864 . \\
303\end{array}$ & $\begin{array}{c}78.948 . \\
039\end{array}$ & $\begin{array}{c}78.031 . \\
774\end{array}$ & $\begin{array}{c}77.115 . \\
510\end{array}$ & $\begin{array}{c}76.199 . \\
246\end{array}$ & $\begin{array}{c}75.080 \\
067\end{array}$ \\
\hline 2016 & $\begin{array}{c}65.793 . \\
869\end{array}$ & $\begin{array}{c}64.837 \\
155\end{array}$ & $\begin{array}{c}63.880 . \\
442\end{array}$ & $\begin{array}{c}62.923 \\
728\end{array}$ & $\begin{array}{c}61.967 . \\
014\end{array}$ & $\begin{array}{c}61.010 \\
301\end{array}$ & $\begin{array}{c}60.368 \\
204\end{array}$ & $\begin{array}{c}59.757 . \\
362\end{array}$ & $\begin{array}{c}59.146 . \\
519\end{array}$ & $\begin{array}{c}58.535 . \\
676\end{array}$ & $\begin{array}{c}57.924 . \\
833\end{array}$ & $\begin{array}{c}57.313 . \\
990\end{array}$ & $\begin{array}{c}56.703 \\
147\end{array}$ \\
\hline 2017 & $\begin{array}{c}84.325 . \\
947\end{array}$ & $\begin{array}{c}83.847 . \\
590\end{array}$ & $\begin{array}{c}83.369 . \\
233\end{array}$ & $\begin{array}{c}82.890 . \\
876\end{array}$ & $\begin{array}{c}82.412 . \\
519\end{array}$ & $\begin{array}{c}81.753 . \\
835\end{array}$ & $\begin{array}{c}81.111 . \\
739\end{array}$ & $\begin{array}{c}80.500 . \\
896\end{array}$ & $\begin{array}{c}79.890 \\
053\end{array}$ & $\begin{array}{c}79.279 \\
210\end{array}$ & $\begin{array}{c}78.309 . \\
391\end{array}$ & $\begin{array}{c}77.087 \\
706\end{array}$ & $\begin{array}{c}75.866 \\
020\end{array}$ \\
\hline 2018 & $\begin{array}{c}93.659 . \\
250\end{array}$ & $\begin{array}{c}92.702 . \\
536\end{array}$ & $\begin{array}{c}91.745 . \\
823\end{array}$ & $\begin{array}{c}90.789 . \\
109\end{array}$ & $\begin{array}{c}89.832 . \\
395\end{array}$ & $\begin{array}{c}88.574 \\
866\end{array}$ & $\begin{array}{c}87.611 . \\
722\end{array}$ & $\begin{array}{c}86.560 \\
618\end{array}$ & $\begin{array}{c}85.338 . \\
932\end{array}$ & $\begin{array}{c}84.117 . \\
247\end{array}$ & $\begin{array}{c}82.895 . \\
561\end{array}$ & $\begin{array}{c}81.673 . \\
875\end{array}$ & $\begin{array}{c}80.164 \\
272\end{array}$ \\
\hline 2019 & $\begin{array}{c}88.002 . \\
584\end{array}$ & $\begin{array}{c}87.045 . \\
870\end{array}$ & $\begin{array}{c}86.089 . \\
156\end{array}$ & $\begin{array}{c}85.132 . \\
443\end{array}$ & $\begin{array}{c}84.175 . \\
729\end{array}$ & $\begin{array}{c}83.219 . \\
015\end{array}$ & $\begin{array}{c}82.499 \\
783\end{array}$ & $\begin{array}{c}81.583 . \\
519\end{array}$ & $\begin{array}{c}80.667 \\
255\end{array}$ & $\begin{array}{c}79.750 . \\
991\end{array}$ & $\begin{array}{c}78.834 \\
726\end{array}$ & $\begin{array}{c}77.749 . \\
834\end{array}$ & $\begin{array}{c}76.528 \\
148\end{array}$ \\
\hline $\begin{array}{l}\text { Rata- } \\
\text { Rata }\end{array}$ & $\begin{array}{c}86.145 . \\
826\end{array}$ & $\begin{array}{c}85.380 . \\
455\end{array}$ & $\begin{array}{c}84.615 . \\
084\end{array}$ & $\begin{array}{c}83.849 . \\
713\end{array}$ & $\begin{array}{c}82.943 \\
223\end{array}$ & $\begin{array}{c}81.924 . \\
382\end{array}$ & $\begin{array}{c}81.135 . \\
425\end{array}$ & $\begin{array}{c}80.323 . \\
508\end{array}$ & $\begin{array}{c}79.404 \\
804\end{array}$ & $\begin{array}{c}78.457 . \\
998\end{array}$ & $\begin{array}{c}77.423 . \\
562\end{array}$ & $\begin{array}{c}76.297 \\
184\end{array}$ & $\begin{array}{c}71.838 \\
276\end{array}$ \\
\hline
\end{tabular}

Tabel 8 merupakan tabel hasil perhitungan water balance debit andalan $35 \%, 37 \%, 39 \%$, 41\%, 43\%, 45\%, 47\%, 49\%, 51\%, 53\%, 55\%, 57\% dan 59\%. Pada Tabel 7 terlihat bahwa pada tahun 2010 daya rata-rata per hari dengan prosentase debit andalan $35 \%$ adalah 100.045,394 kWatt dan daya rata-rata yang dihasilkan dengan prosentase tersebut selama 10 tahun dari tahun 2010 hingga tahun 2019 adalah 86.145,826 kWatt.

Berdasarkan hasil perhitungan debit andalan PLTA saat ini didapatkan prosentase debit andalan sebelum dioptimalisasi sebesar 51,995 \% pada duration curve dan berdasarkan hasil perhitungan mass curve didapatkan prosentase debit andalan setelah dioptimalisasi adalah 39,235 \%. Dari Tabel 7 di atas dengan menggunakan intervolasi dapat diketahui bahwa debit 39,235 \% rata-rata daya yang mampu dihasilkan selama 10 tahun adalah sebesar 84.525,153 kWatt sedangkan debit 51,995 $\%$ yang merupakan debit andalan PLTA saat ini rata-rata daya yang mampu dihasilkan selama 10 tahun adalah sebesar 78.933,768 kWatt. Adapun grafik yang dapat dihasilkan dari tabel tersebut dapat dilihat pada Gambar 8.

Gambar 8 menunjukkan hubungan daya listrik dengan prosentase debit andalan pada duration curve. Daya listrik 71.838,276 kWatt memiliki prosentase debit $59 \%$ pada duration curve. Artinya daya 71.838,276 kWatt dapat terjadi selama $\frac{59}{100} \times 365$ hari yaitu 215,35 hari dalam 1 tahun. Sedangkan daya listrik 76.297,184 kWatt memiliki prosentase $57 \%$ artinya daya tersebut dapat terjadi selama $\frac{57}{100} \times 365$ hari yaitu 208,05 hari dalam 1 tahun.

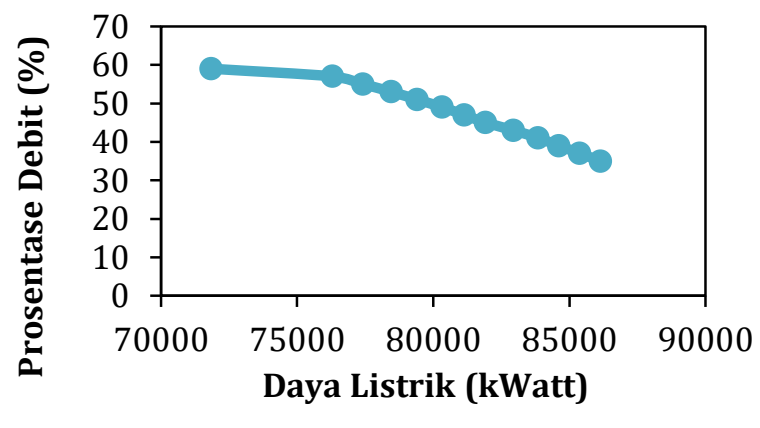

Gambar 8. Persen Debit Andalan (\%) Vs Daya Listrik (kWatt)

Terlihat bahwa semakin besar prosentase debit andalan maka semakin kecil daya listrik yang dihasilkan. Artinya semakin besar prosentase debit andalan maka semakin kecil debit outflow yang dihasilkan untuk membangkitkan daya listrik yang mengakibatkan daya yang dihasilkan juga semakin kecil. Hal ini dapat dilihat pada hasil analisa debit andalan setelah dan sebelum dioptimalisasikan pada sub bab sebelumnya. Debit andalan sebelum dioptimalisasi memiliki prosentase 51,995 \% dengan debit outflow yang dihasilkan yaitu 305,319 $\mathrm{m}^{3} /$ det dan daya listrik rata-rata yang dihasilkan oleh debit outflow tersebut selama 10 tahun adalah sebesar 78.933,768 kWatt. Sedangkan Debit andalan setelah dioptimalisasi memiliki prosentase lebih rendah yaitu 39,235 \% dengan debit outflow lebih besar dari debit outflow yang dihasilkan sebelum dioptimalisasi yaitu 384,465 $\mathrm{m}^{3}$ /det dan daya listrik rata-rata yang mampu dihasilkan selama 10 tahun juga lebih besar yaitu 84.525,153 kWatt. Daya setelah dan sebelum dioptimalisasikan 
selama 10 tahun tersebut memiliki selisih sebesar $5.591,385 \mathrm{kWatt}$.

\section{Perbandingan Daya Setelah dan Sebelum Dioptimalisasikan}

Pada Tabel 6 dan Tabel 7 dihasilkan besar daya listrik sebelum dan setelah dioptimalisasikan. Daya listrik yang dihasilkan dari tabel water balance setelah dan sebelum dioptimalisasikan tersebut dibuat perbandingannya. Perbandingan daya setelah dan sebelum dioptimalisasikan dapat dilihat pada Tabel 9.
Tabel 9 merupakan tabel perbandingan daya yang dapat dibangkitkan PLTA Koto Panjang setelah dan sebelum dioptimalisasikan. Pada tabel terlihat perbandingan daya listrik selama 10 bulan pertama tahun 2010. Nilai debit outflow PLTA dan $P_{\text {hari }}$ pada Tabel 9 sama dengan nilai debit outflow dan $\mathrm{P}_{\text {hari }}$ yang terdapat pada Tabel 6 yaitu yaitu tabel water balance untuk tahun 2010 setelah dioptimalisasikan dan Tabel 7 yaitu tabel water balance untuk tahun 2010 sebelum dioptimalisasikan.

Tabel 9. Perbandingan Daya Setelah dan Sebelum Dioptimalisasikan

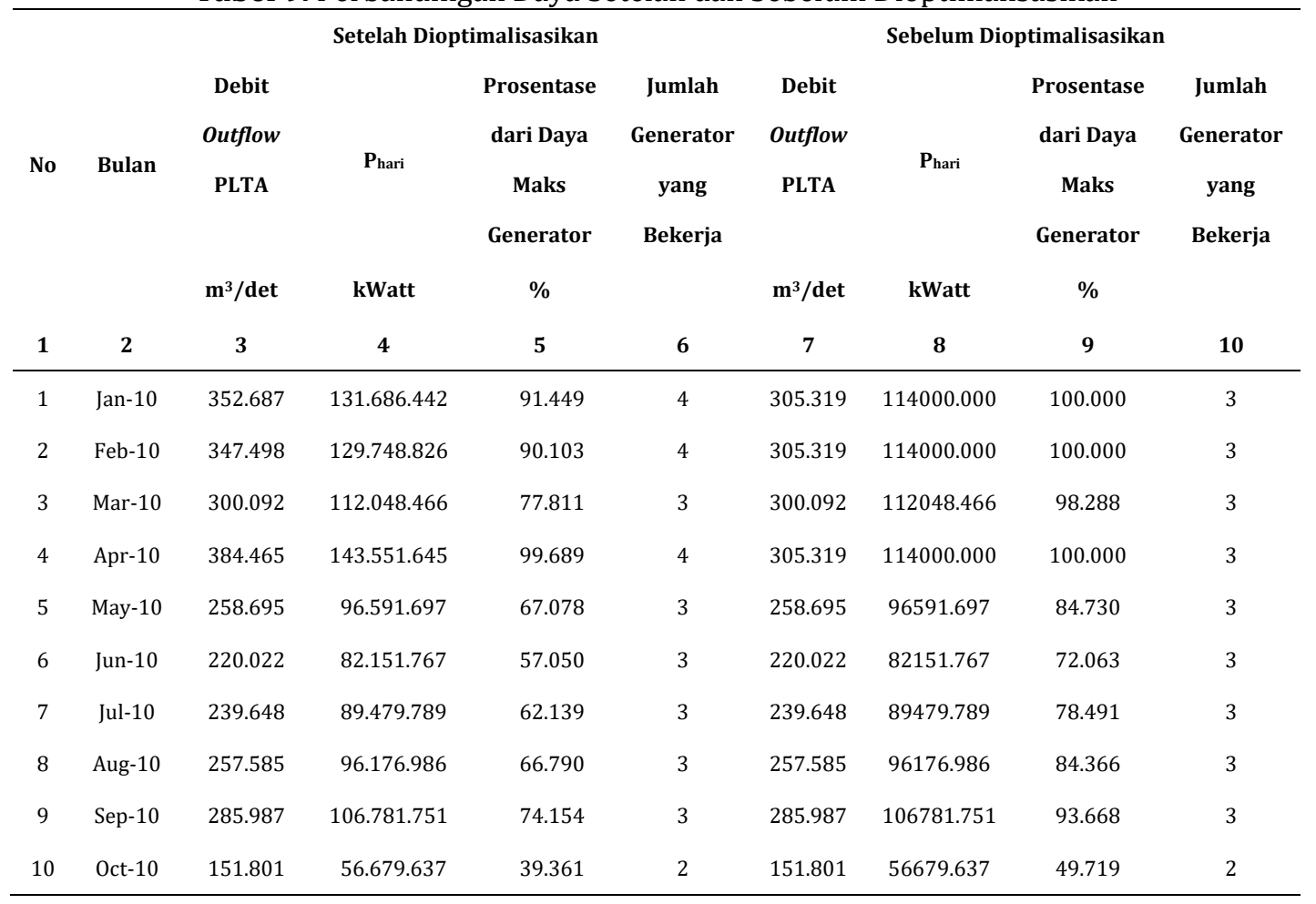

Pada bulan April 2010 terlihat nilai $P_{\text {hari }}$ setelah dioptimalisasikan yaitu 143.551,645 kWatt. Nilai daya tersebut melebihi kemampuan generator PLTA Koto Panjang yang hanya dapat menghasilkan daya maksimal $114 \mathrm{MW}$ atau $114.000 \mathrm{kWatt}$. Sehingga dibutuhkan tambahan 1 generator $30 \mathrm{MW}$ agar dapat membangkitkan daya sebesar 143.551,645 kWatt atau 143,552 MW. Generator 30 MW dibutuhkan karena dengan penambahan daya generator sebesar 30 MW maka daya maksimal yang dapat dibangkitkan oleh PLTA menjadi 144 MW atau 144.000 kWatt. Daya maksimal yang dihasilkan generator tambahan tersebut melebihi dan cukup untuk membangkitkan daya hasil optimalisasi yaitu sebesar 143.551,645 kWatt atau 143,552 MW.

Pada bulan Januari 2010 dapat diketahui nilai prosentase dari daya maksimum generator setelah dioptimalisasikan adalah 91,449 \% dengan jumlah generator yang bekerja adalah 4 generator. Sedangkan nilai prosentase dari daya maksimum generator sebelum dioptimalisasikan adalah $100 \%$ dengan jumlah generator yang bekerja adalah 3 generator. Pada bulan Oktober 2010 terlihat nilai prosentase dari daya maksimum generator setelah dioptimalisasikan adalah 39,361 \% dengan jumlah generator yang bekerja adalah 2 generator. Jumlah generator tersebut sama dengan jumlah generator yang bekerja pada kondisi sebelum dioptimalisasikan namun nilai prosentase dari daya maksimum generator berbeda yaitu 49,719\%. Adapun grafik perbandingan daya sebelum dan setelah dioptimalisasikan dapat dilihat pada Gambar 9.

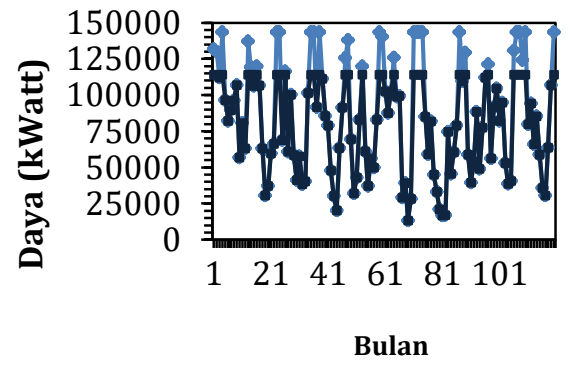

Gambar 9. Grafik Perbandingan Daya Setelah dan Sebelum Dioptimalisasikan 
Keterangan :

Daya PLTA sebelum dioptimalisasikan

Daya PLTA setelah dioptimalisasikan

Pada Gambar 9 pada bulan ke-1 yaitu bulan januari 2010 besar daya yang dihasilkan adalah 131.686,442 kWatt setelah dioptimalisasi dan 114.000 kWatt sebelum dioptimalisasi. Pada gambar terlihat bahwa daya listrik setelah dioptimalisasikan mengalami peningkatan dibandingkan dengan daya listrik sebelum dioptimalisasikan. Namun pola garis daya yang dihasilkan setelah dioptimalisasi umumnya memiliki kecenderungan yang sama dengan pola garis daya yang dihasilkan sebelum dioptimalisasi. Daya listrik sebelum dan sesudah dioptimalisasikan juga dilakukan perbandingan prosentasenya terhadap daya listrik maksimal yang dihasilkan. Hasil dari tabel diplot kedalam grafik yang dapat dilihat pada Gambar 10 dan Gambar 11.

Gambar 10 merupakan grafik prosentase daya yang dihasilkan terhadap daya maksimal yaitu 144 MW yang bekerja dengan 3 generator 38.000 kWatt dan 1 generator 30.000 kWatt. Sedangkan Gambar 11 merupakan grafik prosentase daya yang dihasilkan terhadap daya maksimal yaitu $114 \mathrm{MW}$ yang bekerja dengan 3 generator $38.000 \mathrm{kWatt}$. Pada Gambar 10 dan Gambar 11 di atas terlihat bahwa pola garis prosentase yang dihasilkan setelah dioptimalisasi dan sebelum dioptimalisasi umumnya memiliki kecenderungan yang sama.

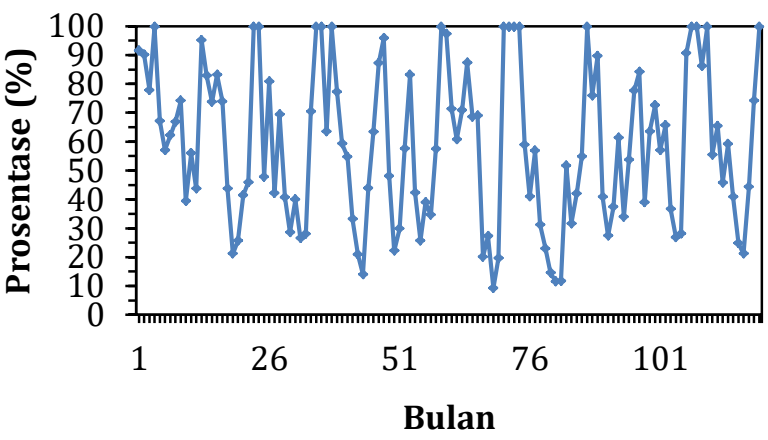

Gambar 10. Grafik Prosentase Daya Terhadap Daya Maksimal (144 MWatt) Setelah Dioptimalisasi

(Bekerja dengan 4 Generator)

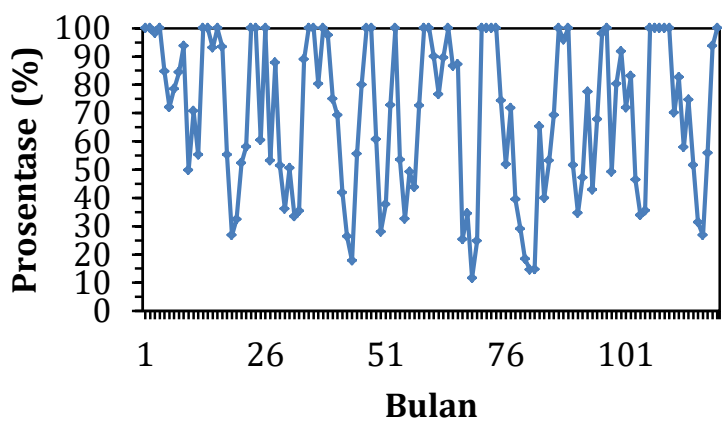

Gambar 11. Grafik Prosentase Daya Terhadap Daya Maksimal (114 MWatt) Sebelum Dioptimalisasi

(Bekerja dengan 3 Generator)

\section{KESIMPULAN}

Dari hasil perhitungan debit andalan dan mass curve didapatkan 305,319 $\mathrm{m}^{3} /$ det dengan prosentase $51,995 \%$ pada duration curve untuk debit andalan PLTA saat ini dan 384,465 $\mathrm{m}^{3} /$ det dengan prosentase 39,235 \% pada duration curve untuk debit andalan PLTA setelah dioptimalisasi. Optimalisasi yang dilakukan pada PLTA Koto Panjang yaitu dengan cara menyesuaikan debit outflow dengan volume air yang ada pada storage saat itu yaitu volume total inflow yang dikurangi volume evaporasi. Debit outflow yang digunakan adalah debit andalan hasil analisa mass curve sebesar 384,465 $\mathrm{m}^{3} /$ det yang dalam perhitungannya menggunakan volume waduk aktif PLTA Koto Panjang. Hasil dari penyesuaian ini terlihat pada kolom $\mathrm{K}_{\mathrm{t}}$ (volume tampungan atau volume berlebih dalam sehari) yang bernilai nol pada tabel water balance. Daya listrik setelah dioptimalisasi adalah sebesar 13.302,315 kWatt pada musim kering dan 143.551,645 kWatt pada musim hujan. Daya listrik di kedua musim tersebut memiliki selisih sebesar 130.249,33 kWatt. Daya listrik yang dihasilkan PLTA saat ini adalah sebesar 13.302,315 kWatt pada musim kering dan 114.000 kWatt pada musim hujan. Sehingga daya listrik yang dihasilkan PLTA setelah dioptimalisasi mengalami kenaikan dari daya listrik sebelum dioptimalisasi. Karena kenaikan daya melebihi kapasitas generator PLTA saat ini, maka terjadi penambahan 1 generator $30.000 \mathrm{kWatt}$ atau $30 \mathrm{MW}$.

\section{REFERENSI}

[1] Menteri Pekerjaan Umum dan Perumahan Rakyat Republik Indonesia, Peraturan Menteri Pekerjaan Umum Dan Perumahan Rakyat Republik Indonesia Nomor 27/PRT/M/2015 tentang Bendungan. Jakarta, Indonesia: https://peraturan.bpk.go.id/Home/Details/ 144525/permen-pupr-no-27prtm2015tahun-2015, 2015.

[2] T. M. Nuramini, "Studi Optimasi Pola Pengoperasian Waduk Bajulmati," Institut Teknologi Sepuluh Nopember, 2017.

[3] D. D. Adhistana, "Rencana Pengoperasian Yang Optimum Pada Potensi Air Waduk Selorejo Untuk Pembangkit Listrik dan Irigasi," Institut Teknologi Sepuluh Nopember, 2017.

[4] D. A. Arismunandar and D. S. Kuwahara, Teknik Tenaga Listrik Jilid I Pembangkitan Dengan Tenaga Air. Jakarta: PT Pradnya Paramita, 2000.

Tim Penyusun Kamus Pembinaan dan Pengembangan Bahasa, Kamus Besar Bahasa Indonesia, Kedua. Jakarta: Balai Pustaka, 1999.

[6] N. Safitri and Suryati, Analisa Rangkaian Listrik (Teori Dasar, Penyelesaian Soal dan 
Soal-Soal Latihan). Politeknik Negeri Lhokseumawe, 2017.

[7] O. F. Patty, Tenaga Air, Pertama. Jakarta: Erlangga, 1995.

[8] Suripin, Sistem Drainase Perkotaan Yang Berkelanjutan. Yogyakarta: Andi Offset, 2004.

[9] K. Mori and Dkk, Hidrologi Untuk Pengairan. Jakarta: PT Pradnya Paramita, 2006.

[10] R. K. Linsley and J. B. Franzini, Teknik Sumber Daya Air Jilid 1, Ketiga. Jakarta: Erlangga, 1985.

[11] S. Sosrodarsono and T. Kensaku, Bendungan Tipe Urugan. Jakarta: PT Pradnya Paramita, 1981.

[12] L. W. Mays and Y.-K. Tung, Hydrosystems Engineering and Management. McGraw-Hill, Inc, 1992.

[13] C. S. Samosir, W. Soetopo, and E. Yuliani, "Optimasi Pola Operasi Waduk Untuk Memenuhi Kebutuhan Energi Pembangkit Listrik Tenaga Air (Studi Kasus Waduk Wonogiri )," Tek. Pengair., vol. 06, no. 1, pp. 108-115, 2015.

[14] D. permukiman dan P. Wilayah, Pengoperasian Waduk Tunggal Pd T-252004-A. Indonesia, 2004.

[15] M. Kurniawan, “Optimasi Struktur Rangka Batang Menggunakan Metode Algoritma Genetika Dengan Kendala Tegangan Dan Probabilitas Kegagalan," J. Saintis, vol. 19, no. 1, pp. 15-23, 2019, doi: 10.25299/saintis.2019.vol19(1).3043.

[16] D. P. Loucks and Dkk, Water Resource Systems Planning And Analysis. Englewood Cliffs, N.J: Prentice-Hall, 1981.

\section{NOMENKLATUR}

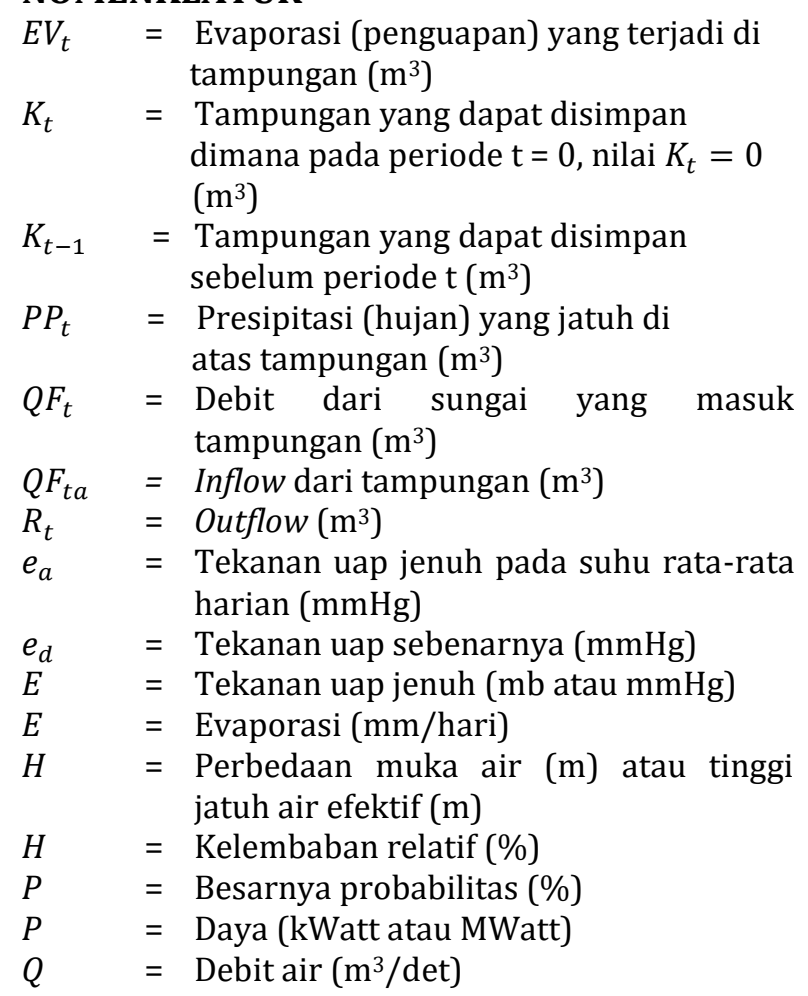

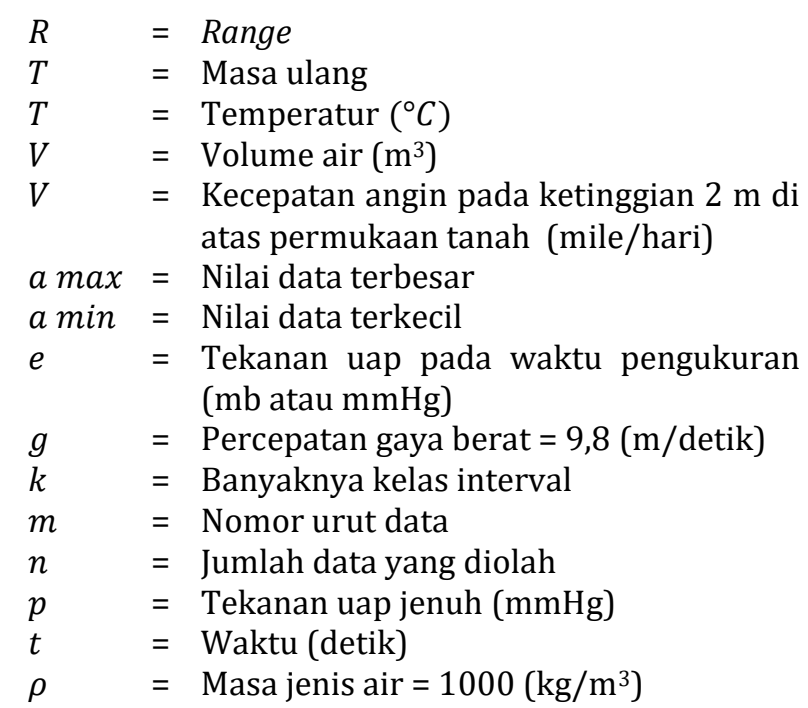


This page is intentionally blank 